University of Nebraska - Lincoln

DigitalCommons@University of Nebraska - Lincoln

1980

\title{
Collecting in Western Nebraska's Cenozoic Strata
}

J. B. Swinehart

University of Nebraska - Lincoln

Follow this and additional works at: https://digitalcommons.unl.edu/conservationsurvey

Part of the Geology Commons, Geomorphology Commons, Hydrology Commons, Paleontology Commons, Sedimentology Commons, Soil Science Commons, and the Stratigraphy Commons

Swinehart, J. B., "Collecting in Western Nebraska's Cenozoic Strata" (1980). Conservation and Survey Division. 642.

https://digitalcommons.unl.edu/conservationsurvey/642

This Article is brought to you for free and open access by the Natural Resources, School of at DigitalCommons@University of Nebraska - Lincoln. It has been accepted for inclusion in Conservation and Survey Division by an authorized administrator of DigitalCommons@University of Nebraska - Lincoln. 
To motorists traveling on Interstate 80 the geology of western Nebraska probably looks quite simple. The few visible outcrops appear to contain horizontal, rather unexciting strata, certainly nothing to write home about. Fortunately the pioneers traveled the Great Platte River Road past interesting outcrops like Ash Hollow, Courthouse and Jail rocks, Chimney Rock, and Scotts Bluff, all of which provided some inspiration for diaries and letters home.

\section{Introduction}

Exposures along the North Platte and Niobrara river valleys and on Pine Ridge allow a glimpse of the fascinating and complex geologic history of western Nebraska during the last 35 million years. Geologists and paleontologists have been studying the sequence of Cenozoic strata in this area since the late 1800 s. Prior to the 1950s the Cenozoic geologic framework was established on outcrop data. Since that time a considerable amount of information on the subsurface geology of Nebraska has been obtained by drilling holes for geohydrologic information, oil and gas tests, and irrigation wells. This data has provided a more complete picture of Cenozoic geology.

\section{Stratigraphy}

Formations are the fundamental lithostratigraphic units for classification of rocks and sediments. They are defined solely on lithologic features (grain size, composition, structure, etc.), and their boundaries generally reflect significant changes in lithology. A formation may contain a variety of rock types, and its thickness is not an important consideration. It must, however, be mappable from outcrop to outcrop or correlatable in the subsurface. Formations may be subdivided into members or beds, and two or more formations having certain unifying characteristics can be combined to constitute a group. Group ranking provides a very handy means of generalizing and simplifying the complexities of regional lithostratigraphy, since formation nomenclature, particularly for continental deposits, can be as confusing to the professional as to the amateur geologist.

Difficulties in correlating Cenozoic strata of western Nebraska and adjoining areas arise because many formations contain similar lithologies or "look-alikes." Moreover, major outcrops may be widely separated and have only parts of some formations exposed. Also, contacts between formations or groups are not necessarily horizontal because many formations were deposited in ancient river valleys that have been eroded deep into underlying formations. Because of these problems, the establishment and correlation of valid lithostratigraphic units often requires detailed geologic mapping combined with subsurface, petrologic, and paleontologic data.

The Cenozoic (Tertiary plus Quaternary) sedimentary strata of western Nebraska are part of an extensive sequence of continental deposits extending eastward from the Laramie, Front Range, and Hartville uplifts. The geologic history of this region during the last 35 million years is largely a story of the interactions among the following: (1) Agents of deposition-rivers and streams (fluvial sedimentation) versus wind (eolian sedimentation); (2) sources of sediment-igneous, metamorphic, and sedimentary rocks in the Rocky Mountain uplifts of Colorado and Wyoming versus debris from volcanoes in Colorado, Wyoming, and the Great Basin; and (3) erosion. In turn, these factors are controlled to a large part by tectonics and climate.

Strata of Cenozoic age in western Nebraska can be divided into one of the following four groups of rocks and sediment: Three formal groups-White River, Arikaree, and Ogallala-and one informal group comprising unconsolidated silt, sand, and gravel deposited during the latest Cenozoic. The many gaps or unconformities in this rock record are the result of erosion or nondeposition. The largest unconformity or missing interval of time and rock is at the base of the White River Group where approximately 30 million years of Cenozoic history is not represented by any strata in western Nebraska.

\section{Collecting in \\ Western Nebraska's Cenozoic Strata}

JAMES B. SWINEHART

University of Nebraska

Lincoln, Nebraska 68588 


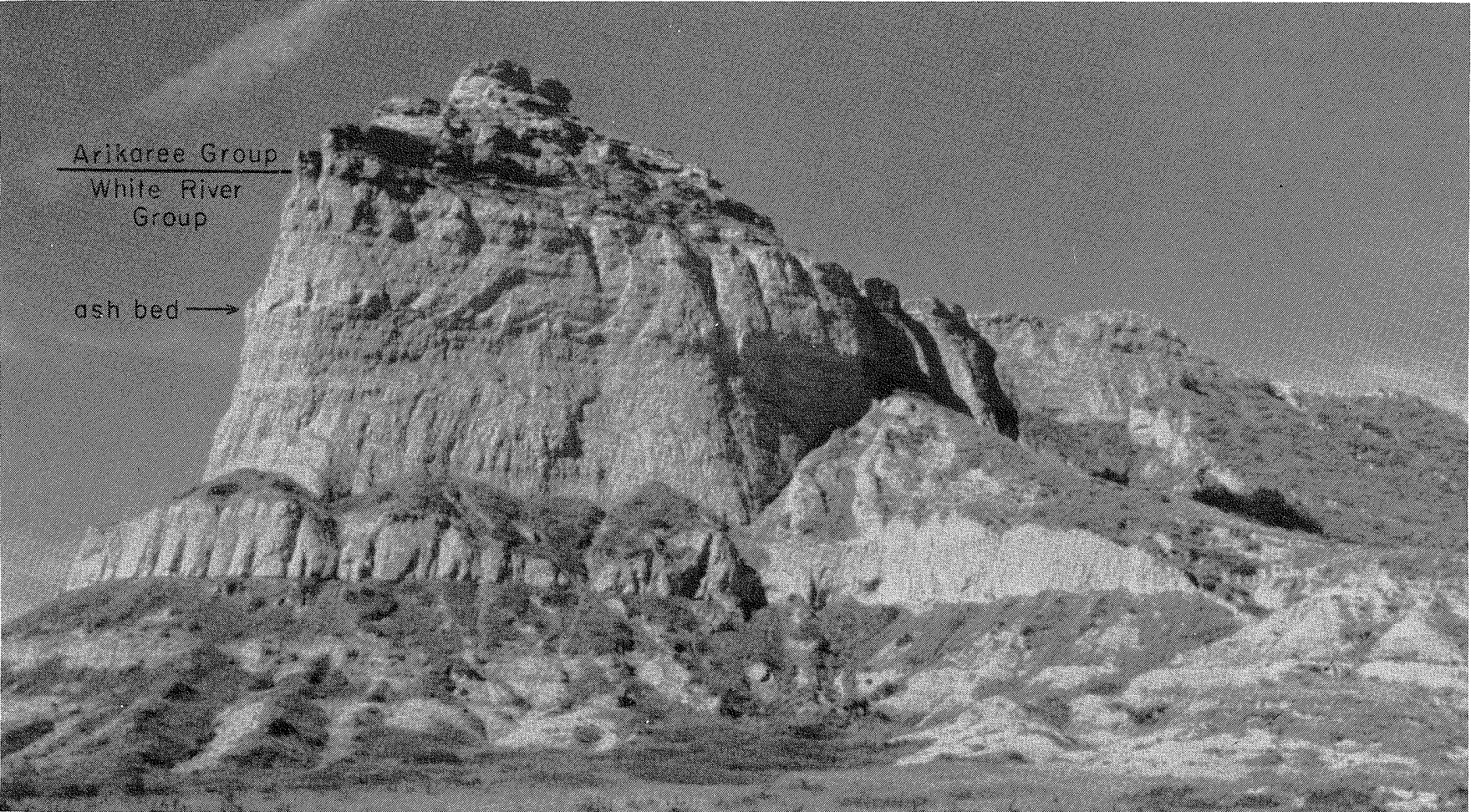

Eagle Rock at Scotts Bluff National Monument. The contact between the siltstones of the White River Group and the sandstones of the Arikaree Group is easily recognized in this area.

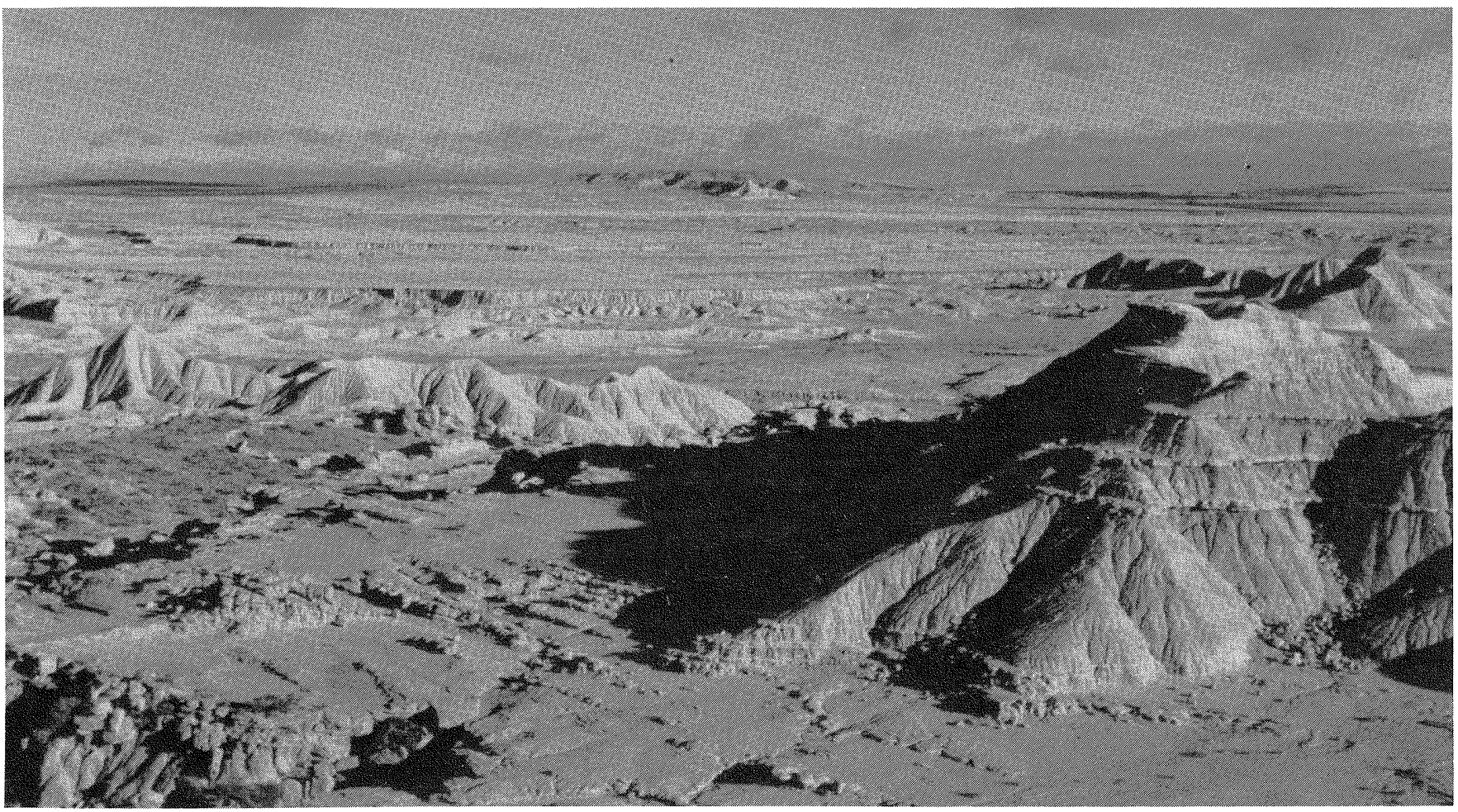

The little badlands of the White River Group at Toadstool Park, northwest of Crawford, Nebraska. Thin sandstone beds are sandwiched between thick, fine-grained clayey siltstone beds. Excellent exposures of channel-form fluvial sandstones also occur here. 



Above: Geologic cross-sections through western Nebraska. Cross-section AB follows State Highway 61 , and crosssection CD generally follows State Highways 71 and 29.

Left: Extent of Tertiary rocks in Nebraska and adjacent areas. Areas of Quaternary sediments have been omitted.

White River Group-The oldest Cenozoic strata of western Nebraska overlie the truncated surface of Cretaceous rocks and consist predominantly of siltstone and claystone belonging to the White River Group. These rocks are very interesting because they are composed primarily of volcanic dust or ash and contain only a small amount of nonvolcanic material. Microscopic, angular shards of volcanic glass and fragments of volcanic plagioclase are the most common grains. The location of the volcanic centers that produced this ash are not well known but may have been as far away as Nevada or as close as central Colorado. Wherever they were located, tremendous eruptions threw huge quantities of volcanic dust into the atmosphere throughout deposition of the White River Group. This material was carried eastward by high altitude winds and slowly deposited as a succession of blankets over western $\mathrm{Ne}$ braska and adjacent areas. Distinct beds, composed almost entirely of glass shards, also were deposited and probably represent very rapid accumulation of material from a single eruption. One such ash bed occurs in the upper part of the White River Group and is known to extend throughout an area of 7,000 square miles in western Nebraska. The maximum thickness of the White River Group is about 1,100 feet. 
The clay-rich rocks of the White River Group commonly erode to a "badlands" topography. This fascinating land form is best seen in exposures north of the Pine Ridge between Chadron and the Toadstool Park area.

Sandstones and siltstones deposited as stream channel and floodplain sediments make up only a small part of the White River Group. The basal part of the Chadron Formation locally contains coarse river gravels. These are well exposed north of Crawford and contain "fortification" agates and petrified wood transported from the Hartville Uplift and Laramie Range.

Arikaree Group-Most of the Arikaree Group consists of gray to buff, well sorted, very fine-grained sandstones and sandy siltstones. Like the White River Group, most of these are interpreted to have been wind deposited. They generally contain 25 to 50 percent glass shards and other volcanic grains-not as high a percentage as usually found in the White River Group. A period of erosion preceded deposition of the Arikaree, and several major valley systems were eroded into the underlying White River Group. The oldest formation of the Arikaree, the Gering, fills these valleys. It consists of gray, fine to mediumgrained sandstones, along with some coarse sand and gravel beds deposited by rivers draining the Laramie and Front ranges. Fluvial deposits occur throughout the Arikaree but are common only in the Gering Formation. The Harrison and Monroe Creek Formations are very similar in lithology and extremely difficult to differentiate. The maximum thickness of the Arikaree Group is about 850 feet.

Hard ledges of carbonate-cemented sandstone called pipy concretions are a characteristic feature of many Arikaree outcrops. These concretions probably formed soon after deposition and burial of the sand when calcium carbonate was precipitated out of the groundwater and into the pore spaces around individual sand grains.

Like the White River Group, the greater part of Arikaree sediment was supplied by western volcanoes. However the Arikaree is over a smaller area in western Nebraska than the White River Group. Together these two groups form most of the outcrops of the Wildcat and Pine Ridge.

Ogallala Group-The rocks of the Ogallala Group consist of a wide variety of lithologies ranging from claystones to poorly sorted sandstones to coarse gravel. Moderately well sorted, medium-grained sandstone is probably the most common lithology in western Nebraska. South of the North Platte River coarse sand and gravel is very common in the Ogallala Group. All of these lithologies occur in a bewidlering assortment of fluvial deposits, many of which fill deep cuts into underlying strata. For example, in an area of a few square miles on the high divide between the Niobrara and North Platte Rivers at least three separate stratigraphic units within the Ogallala are

James Swinehart is a research geologist with the Conservation and Survey Division-Institute of Agriculture and Natural Resources at the University of Nebraska, Lincoln, Nebraska.

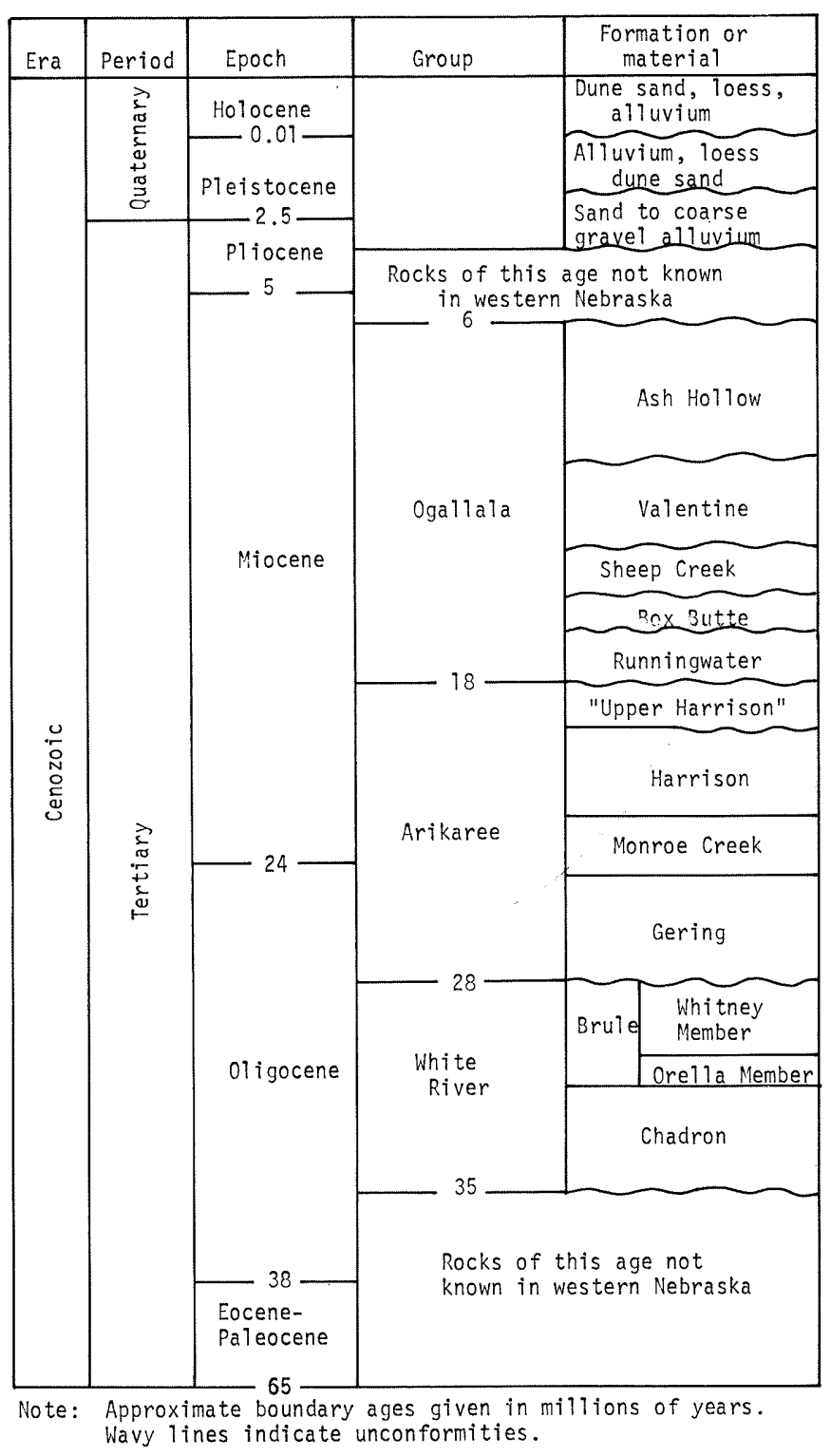

Generalized lithostratigraphic classification of Cenozoic rocks in Western Nebraska. This is not a complete list of named formations; current research indicates additional units need to be defined.

successively cut into and deposited over one another. These cycles of deposition and erosion span 10 million years. In the southwestern part of the Panhandle only the upper part of the Ogallala is known to be present, yet it fills a valley eroded 500 feet into the White River Group. The Ogallala Group has a maximum thickness of about 700 feet.

In contrast to the Arikaree and White River groups the Ogallala contains only small amounts of glass shards and other fine-grained volcanic debris. However, discontinuous volcanic ash beds occur in most of the formations comprising the group.

The Ogallala is the most widespread Tertiary group in Nebraska. It has been recognized throughout most of the Great Plains from Texas to South Dakota and is one of the major aquifers of the United States. 
Youngest Cenozoic-An unconformity encompassing several million years occurs between the Ogallala Group and unconsolidated deposits of late Pliocene and Quaternary age. The oldest of these deposits is a complex and extensive body of river-deposited sand and coarse gravels derived from the Laramie and Front ranges. The coarsest material occurs in narrow channels eroded 200 feet deep into Tertiary age rocks. The most extensive outcrops border the north side of the North Platte River valley, where they have been called the Broadwater Formation. This unit also underlies most of the central and southern Sand Hills. Younger and less extensive episodes of fluvial deposition that occurred between periods of erosion are preserved as terraces throughout western Nebraska. Many of these are probably related to periods of glaciation in the Rockies.

During the late Quaternary wind-deposited silt, called loess, was laid down in many parts of Nebraska. Magnificent exposures of this loess can be found on the south side of Lake McConaughy along State Highway 26. Unlike wind deposited silt of the White River Group, this Quaternary loess contains very little volcanic material.

The youngest and most impressive area of wind-deposited

\section{Fossil Collecting}

The Cenozoic strata of Nebraska and adjoining areas have yielded an almost incredible variety of vertebrate fossils-from elephants, mice, and sabre tooth cats to crocodiles, frogs, and birds. The widespread and locally abundant occurrences of these fossils have drawn a steady flow of "bone diggers" into the area. Their findings have gone to museums around the world. In Nebraska, the State Museum in Lincoln and Trailside Museum in Ft. Robinson have displays featuring Cenozoic fossils. At Agate National Monument north of Scottsbluff, visitors can see bones in place at an actual fossil quarry.

\section{Mineral Collecting Areas}

White River Group gravels crop out in the grasslands about 20 miles north of Crawford and contain agate, jasper, wood, and other cuttable materials. Chalcedony of very high quality can be found in the fine-grained White River rocks in this same area.

Terraces along the South Platte and North Platte Rivers and their tributaries yield a variety of quartz materials including agate, jasper, and wood. Older gravel deposits occur in the uplands adjacent to these rivers and contain similar materials. Gravel bars on all streams in the southern part of the Panhandle are excellent collecting areas. sediment in Nebraska is the Sand Hills. Sand dunes, some over 300 feet high and 20 miles long, cover 20,000 square miles of central Nebraska. Now stabilized by vegetation, the Sand Hills are the largest single area of sand dunes in the Western Hemisphere. Recent evidence suggests that a majority of the dunes in the Sand Hills formed between 3,000 and 7,000 years ago during a dry period that affected the entire Midwest. In what recently was a desert, the grass-frozen dunes are now one of the great cattle producing areas of the world.

\section{Structure}

The most prominent structural feature in western Nebraska is the Chadron Arch. It is a broad asymmetrical flexure trending northwest-southeast across west-central Nebraska. While most movement on the arch dates from the Cretaceous or before, sporadic movements probably occurred through the Cenozoic. Several small earthquakes have been associated with the arch in modern times.

Field mapping and test drilling by geologists at the University of Nebraska have documented faulting with up to 250 feet of displacement in Arikaree and White River group rocks in northwest Nebraska. Further research likely will discover additional and younger faulting.

\section{Summary}

Cenozoic rocks of western Nebraska are a record of the fascinating history of erosion, deposition, tectonism, and climate during the last 35 million years. It is not, as might first be thought, simply a story of rivers transporting material eroded from the Rocky Mountains and depositing it on the plains. A surprisingly tremendous volume of fine volcanic debris was blown into Nebraska from the west during the middle Cenozoic. This glass-rich material slowly blanketed and built up the landscape during deposition of the White River and Arikaree groups. During late Cenozoic times, fluvial deposition and erosion was the order of the day. The development of a great sea of sand dunes adds a final twist to this intriguing story.

\section{Suggested Readings}

Keech, C. F., and Bentall, R. 1971. Dunes on the plains: Conservation and Survey Div., Univ. of Neb., Resource Rept. no. 4, 18 p.

Pabian, R. K. 1971. Minerals and gemstones of Nebraska: Conservation and Survey Div., Univ. of Neb., Ed. Circ. no. $2,80 \mathrm{p}$.

Pabian, R. K., and Swinehart, J. B. 1979. Geologic history of Scotts Bluff National Monument: Conservation and Survey Div., Univ. of Neb., Ed. Circ. no. 3, 26 p.

Robinson, P. 1972. Tertiary history: in geologic atlas of the Rocky Mountain region, U.S.A. Rocky Mtn. Assoc. Geol., p. 233-242.

Souders, V. L., Swinehart, J. B., and DeGraw, H. M. in press. Lithostratigraphy of Cenozoic and Upper Mesozoic rocks: western Nebraska, Conservation and Survey Div., Univ. of Neb., Neb. Geol. Survey Paper 20.

Stout, T. M., and others. 1971. Guidebook to the Late Pliocene and Early Pleistocene of Nebraska: Conservation and Survey Div., Univ. of Neb. 108 p. 